met rust en niet min gunstige bejegeninge der regenten den handel to Suratte hebben gedreven gehadt, dog integendeel tracteert men haar nu daar soo, als het daar al om $t$ rucken en plucken en om te hebben van d'onse te doen, sulx dat genoegsaem blykt men onse natie daar niet meer agt nog extimeert, daaromme geen wonder synde, dat om die oorsaken d'onse den lust tot langer daar te blyven daardoor vergaat, $\ldots{ }^{1}$ ) gedurige vrese dood sulx ook al vermeerderen over sulx niet in Suratte woonplaats te houden, weynig meer te doen, dierhalven alsmede begere dat UEd. daarinne voorsiet, tot welkers uijtvoer niemand buijten den Coning en UEd., die den Suratse gouverneur zyd, erkennen en gevolglijck is het ook billik dat andre haar met onse saken niet sullen bemoeyen.

't Antwoord van den Gouverneur was: laat die van UEd. natie en die haar saken hier te verrigten hebben by mij komen. ' $k$ Sal deselve met Gods toelatinge soo dat behoord in alle gelegentheyd veel eer en alle vrintschap bewysen. Onderstond: gecollationeerd en met de minute d'accoorde bevonden, Suratte ady $4^{\text {e }}$ April 1675 en was getekent Gerrit Hooft, Dirc de ${ }^{2}$ ) Clercq.

\title{
CCCLXI. LOMBOK.
}

16 Maart 1675. ${ }^{3}$ )

Het spreekt wel van zelf, dat de Nederlanders na hunne komst in den Oost-Indischen Archipel en na hunne aanrakingen met Bali (1597, 1601, vgl. Corp. Dipl. I, bldz. 15) al spoedig bekend raakten met het bestaan van Lombok, te eerder omdat ,de Coninck van Baly" rechten pretendeerde op dit eiland. Toch kwamen de directe aanrakingen (behalve dan eenige handelsbetrekkingen zonder groote beterkenis) daarmede niet langs den weg van Bali maar langs den weg van Makassar en Soembawa, welke beide eveneens Lombok tot hun gẹied rekenden ( $\mathrm{Zie}$ o.a. hiervóór, Register, Realia II, bldz. 150, v.). Toen wij in 1673 een beetje vasten voet kregen op Soembawa, hebben wij van daar uit eenige „regenten” van Lombok, een verzamelplaats van Makassaarsche uitgewekenen, tot een contract weten

1) Onleesbaar.

2) Vermoedelijk een schrijffout.

3) Uit het Contractboek. In margine staat daar: „Macasser 1675”. - Ook bij W. Cool, Lombok, bldz. 215. - In het exemplaar in het Landsarchief te Batavia wordt het aangeduid als: „Contract obligatie ten laste.der regenten van Sallaparang en ten voordeele van d' E. Comp. gepasseert”. Eveneens in de Verbalen-Nederburgh, die er echter foutief bijvoegen: „gepasseerd op Macasser". 
te dwingen. (Cool, Lombok, bldz. 195 v.v. en de daar genoemde litteratuur; Dagh-Register 1675, bldz. 33; Heeres, Kleine Soenda-eilanden in Feestbundel-Veth, bldz. 179).

Op heyden den 16 Maart $^{1}$ ) 1675 compareerde ter presentie van de ondergenoemde getuijgen, als rading Abdi Wierassantana, rading Kawissanaijer Coesing, aria Boessing, ${ }^{2}$ ) tommagon, dewelke mits desen tot een pand wegens veel harer begane fouten aen hun koning ${ }^{3}$ ) en $\mathrm{d}^{\prime} \mathrm{Ed}$. Comp ${ }^{\mathrm{te}}$ beloven, binnen den tyd van 3 naastvolgende jaren aen welgen ${ }^{e} \mathrm{Ed}$. Comp ${ }^{\text {e }}$ sullen opbrengen vyf duysent ofte vyftien duijsent ${ }^{4}$ ) picols sappanhout; dog by aldien gem $^{\text {te }}$ regenten van Sallaparang in gebreke vant selve niet te betalen mogte blyven, soo stelt Syn Hoogheyt van Sumbawa sig daar als borg voor om 't selve $\mathrm{p}^{\mathrm{e}}$ eerster aenmaning aen $\mathrm{d}^{\prime} \mathrm{Ed}$. Comp ${ }^{\text {le }}$ te sullen voldoen, en ten waare gen ${ }^{e} \mathrm{Sijn} \mathrm{Hoogh}^{t}$ bij overlyden binnen desen tijd van de wereld quam te schyden, of wel door andre intervallen, dat alsdan syn nakomelingen ende diegene die in sijn plaats als koning sal komen te succederen, ook gehouden sal wesen den bovengen ${ }^{\circ}$ taxt van vyjtien duysend picols sappanhout, gelyck gesegt, aend' Ed. Comp ${ }^{10}$ te voldoen.

Alle dit gene voors ${ }^{e}$ staat, belooft meer gem $^{\text {te }}$ Syn Hoogheyt met alle cinceriteyt naar te sullen komen en dierhalven tot teken der waarheyd den desen met Syn gewonelyke handtekening becragtigt heeft. 'Ter sijden stond: ons present als getuygen en was geteekent Jan France Holsteijn, ${ }^{5}$ ) Gerrit Coster en Coenraat van Breijtenbach. ${ }^{6}$ )

\section{SOEMBAWA-MAKASSAR.}

\section{Mei-23 Juli $1675 .^{7}$ )}

In 1674 was dan een overeenkomst gesloten met Soembawa, waarin dit land tot bondgenoot der Compagnie werd verklaard. Maar „de capteyn,

1). Cool heeft „19 Maart”.

2) Cool spelt de namen iets anders, waarschijnlijk echter nog meer foutief.

3) Van Soembawa?

4) Dezelfde zonderlinge bepaling bij Cool. Kan ook na 5000 het woordje ,ieder" zijn weggevallen?

5) De leider der expeditie.

6) Cool spreekt op bldz. 216 waarschijnlijk ten onrechte van „Bredenburgh”.

7) Uit het Contractboek. - Ook in het Landsarchief te Batavia. 